\title{
Bibelteologi som skrift?
}

\author{
Professor dr.theol. Kàre Berge
}

Niels Peter Lemche: Det gamle Testamente mellem teologi og historie. Den historisk-kritiske bibelforsknings storhed og fald. København: Forlaget Anis 2008. 407 s. Kr. 389. Gammeltestamentlig og bibelsk teologi, ti forelasninger. København: Forlaget Anis 2009. 219 s. Kr. 249.

\begin{abstract}
This article reviews two books of N. P. Lemche (also published in USA). Lemche discusses how to make biblical theology "after the collapse of history" in the sense of the Copenhagen school. Biblical theology should be based on the texts and narratives not on history. This does not, however, mean a return to literary criticism or structuralism. Biblical texts, in Lemche's view, should be regarded as arbitrary cultural artifacts, which have to be studied as cultural representations of social conditions in the pre-Christian centuries.
\end{abstract}

Key words: Old Testament - Biblical Theology - Israel's History - Exegesis - Method.

Kan det komme bibelteologi fra København? Den gammeltestamentlige "Københavnerskole" er mer kjent for å dekonstruere enn å konstruere, noe Niels Peter Lemche også innrømmer i sitt forord til den ene boken: "Den har været kendetegnet af sit radikale opgør med ældre forskning og dens historiske rekonstruktioner". Disse to bind sammenfatter Lemches oppgjør med den historisk-kritiske forskning siden 1983, men han gir i "teologiboken" (den minst omfangsrike av de to bøker) en skisse til hvorledes bibelsk teologi nå bør konstrueres etter dette oppgjør. Derfor vil jeg først og fremst oppholde meg ved denne bok. Den annen bok kan leses som en nærmere begrunnelse for de argumenter som fremsettes i denne.

Teologiboken er en samling av ti kapitler opprinnelig holdt som forelesninger i 2006. Strukturen er følgende: Den starter i J.P. Gablers (siste halvdel av 1700-tallet) todeling mellom bibelsk og dogmatisk teologi, og meget av diskusjonen handler om hva dette skille egentlig består i. Den reiser spørsmålet om hvilken tekst gammeltestamentlig teologi arbeider med, den problematiserer kanonbegrepet for en historisk tekstanalyse, før den gir en oversikt over de "klassis- 
ke" bibelteologer (Köhler, Vriezen, Eichrodt, von Rad og Kaiser). Derfra går Lemche over til å behandle det som gjerne er blitt kalt "historiens kollaps" og de konsekvenser det har fått for gtl bibelteologi. Begrepet forbindes gjerne med L. Perdues bok med samme tittel, men Lemche er ikke særlig interessert i hans postmoderne dekonstruksjon av historiebegrepet; det er historieforskningens egen dekonstruksjon av det bibelske historiebilde som opptar Lemche. Etter dette blir fremstillingen mindre kronologisk og mer tematisk, idet den behandler temaer som kanonisk teologi (Childs, Rendtorff), frelseshistorien, den nordamerikanske "biblical theology" samt Brueggemann, før den avslutter med to kapitler om forholdet mellom GT og NT og om "Københavnerskolens" bidrag.

Hvorledes vil så Lemche konstruere en bibelteologi? Det vil han gjøre på basis av to grunnleggende oppgjør med tidligere forskning:

For det første. Bibelen (GT) er fortellinger, ikke historie. Med dette tar han oppgjør med en fortolkningstradisjon som iflg. Lemche går tilbake til romantikken. Likesom historikerne fikk i oppgave å legitimere de nye nasjonalstater ved å bevise deres eldgamle opphav, ble de gtl fortellinger transformert (i forskernes bevissthet) til eldgamle kilder til et Jernalderens Israel: "Det gamle Israel opstod så at sige i romantikken som følge af den nye definition af historiebegrebet" (s. 16). Men dermed ble GT-tekstene kilder til noe annet enn teologi: enten religionshistorien eller profanhistorien.

Formuleringene er misforståelige. Selvsagt mener ikke Lemche at eldre teologiske lærde som Luther, for eksempel, i datidens forstand ikke betraktet David, Salomo osv. som skikkelser i den såkalte "realhistorie". Lemches påstand må forstås presist slik den er formulert: Det er historien som legitimering han omtaler. Bibelboken inngikk allianse med romantikkens nasjonalitetsideologier i den forstand at bibelteologene fikk samme funksjon som historikerne, å legitimere en nasjonal ideologi, henholdsvis en kristelig ideologi, ved en meget gammel historie, det såkalte bibelske Israel. Man bruker Skriften som kilde til en historie som så igjen skal legitimere et prosjekt i nåtiden, nemlig å legitimere det europeiske nasjonsprosjekt, inkludert den euro-amerikanske kolonialisme (se s. 93-98).

Lemche tegner med bred pensel. Nasjonalitetsforskerne diskuterer forholdet mellom europeisk nasjonalitet forstått etter en "primordial" modell (nasjonalfølelsen har urgamle røtter) eller etter en konstruksjonsmodell (det dreier seg om "invented national traditions"). Men på den annen side rammer han det forhold at den forståelse av GT som etablerte seg på 1800-tallet, har sterke paralleller til datidens konstruksjon av nasjonale og etniske myter. Nå er det jo slik at de nasjonale mytemakere faktisk brukte bibelen til sine prosjekter. Videre 
kan vi fastslå at GT tegner myten om det ene folk, på måter som vi kjenner fra forskningen på etnisk-nasjonale opphavsmyter i ulike kulturer: myten om at man ikke opprinnelig hørte til i landet, men fikk det fra de uverdige urinnvånere; myten om å være spesielt utvalgt, myten om et felles etnisk opphav, osv.

Det annet grunnlag for Lemches bibelteologi er følgende: Tradisjonell historisk-kritisk bibelforskning har i realiteten skilt GT og NT ad, sier Lemche. Ikke bare var GT redusert til en kilde, fjernt i tid fra NT, til "Israels" Jernalder; den kunne også bare fungere i en kristen teologi gjennom en betydelig fordreining, nærmest gjennom en feilaktig bruk av GT, noe eksegetene da allerede fant i NT selv. På denne måte fikk GT ingen reell teologisk betydning i kristen teologi; kun gjennom en fordreining og omtolkning av GT var skriftet brukbart i den sammenheng.

Lemche vil altså gjenvinne GT's teologiske betydning i kristen teologi. Det gjør han ved å vise til at GT ligger tett opp til den antikke jødedom (jødedommen på Jesu tid), og både denne jødedoms ulike retninger og Det nye testamente (kristendommen) er naturlige fortsettelser av GT. Det er særlig to trekk som skaper denne forbindelse mellom GT/antikk jødedom og NT: det er eskatologien ("flugten ind i fremtiden”, s. 203) og messiasforventningen. Således fastslår Lemche "at denne messiastro ikke er noget, der er påklistret en gammel, israelitisk gudstro. Den er til stede i Det Gamle Testamente, endda langt mer massivt, end man ofte har regnet med" (s. 206). "Bibelsk teologi handler om, hvorledes kristendommen brydes med sin jødiske arv og skaber nye synteser herudaf' (s. 206).

Lemches bok beveger seg frem og tilbake mellom en avvisning av "realhistoriens" betydning for gtl teologi, og teksten lest som en strukturell eller lingvistisk enhet i betydninger som ligger nær lesninger hos HJ Lundager Jensen, W Brueggemann o.fl. som han likevel ikke føler seg komfortabel med. Hvorfor ikke? Fordi Lemche fastholder at GT-tekstene har historiske referenter i betyding av at de tilhørte et samfunn: De handler, for eksempel, om det gode liv for noen (for å knytte an til hans kritikk av Lundager Jensen), de avspeiler en snever elites religion i det jødiske samfunn, for Lemche i tiden ca. 100 f.Kr. Lemche vil derfor aldri kunne slippe historien når han skal skrive en gtl bibelteologi. Men likevel anser han det som et hovedproblem i bibelteologiens forskningshistorie at man nettopp betraktet teologi enten som historie, eller som religion idet man forsto bibelen som kilde til religionshistorien. Hvorledes henger dette sammen? Det henger sammen fordi Lemche ikke forstår tekstene som historisk kilde til religiøse institusjoner, som tempel, sabbat og kult, på grunnlag av hvilke man altså kan konstruere hvordan det religiøse liv fak- 
tisk utspant seg i århundrene, men som konstrukter - kall det gjerne samfunns- eller virkelighetstolkninger - som likevel har en referanseramme i det samfunn og den kultur forfatterne var del av. Det er ikke bare om den prestelige teologi at vi ikke vet om den er et utopisk konstrukt, et ideal heller enn beskrivelse av en eksisterende størrelse, templet og tempelritualene. Det gjelder også det deuteronomistiske historieverks historiefortelling. Den bærer umiskjennelige trekk av det vi kan kalle en nasjonal-etnisk myte.

Ser vi nærmere etter, er det dette som ligger under hele Lemches produksjon, nemlig idet han hele tiden bruker det sosiologiske og samfunnsfaglige begreps- og analyseapparat for å beskrive det palestinensiske samfunn som tekstene reflekterer, ikke i en fjern fortid men på den tid vi vet at disse tekstene eksisterte (tilnærmet) i sin helhet, i det første - annet århundre f.Kr. Slik sett vil Lemche aldri kunne slippe tekstens samfunnsmessige referanseramme og gi seg hen til en ren tekstlesning, heller ikke i sin teologi.

Derfor er det egentlige bibelteologiske prosjekt som Lemche uttegner, et prosjekt som skal forstå tekstene som kulturell symbolisering eller representasjon av sosiale strukturer og maktforhold. Sagt på en annen måte, dreier det seg egentlig, selv om Lemche aldri uttrykker seg slik, om å forstå GT som et kulturelt artefakt, et relativt arbitrært stykke fra den jødiske, vi kunne også si østmediterrane kultur i tiden like før vår tidsregning.

Av dette gir det seg selv at bibelteologiens prosjekt består i å analysere dette konstrukt. Siden Bibelen i vesentlig grad presenterer seg for sine lesere som aktualisert fortid (handler altså om fortidens betydning for lesernes samtid), dreier det seg egentlig om å forstå GT som erindringsbearbeidelse. Heller ikke dette er uttrykkelig sagt hos Lemche, men en rekke formuleringer hos ham bekrefter at det er i den retning han peker: Han spør hvorledes antikke forfattere taler om fortiden, han fastslår at det er 'en konstrueret, 'opfunden' historie hvis betydning ikke ligger i sammenhængen eller mangelen på sammenhæng med fortiden, men i selve konstruktionen" (s. 194), han sier at den gtl fortelling står på egne ben og behøver ikke en historisk backup. Dette er uttrykk som ligger nær dem vi finner i Eric Hobsbawms tale om "invented tradition", et uttrykk han bruker om de nasjonale fortellinger, konstrukter og myter fra romantikken og på 1800-tallet, de som tjente til å legitimere bl.a. den skotske nasjonalfølelse og identitet. Det er således ikke hos Lemche, en "flukt" inn i det litterære univers i betydning av den litteraturkritiske skoleretning, eller i tekstene som uttrykk for semiotiske dybdestrukturer (som hos Lundager Jensen, se Lemche s. 91), eller i mindre teknisk forstand, i fortellingene som beskrivelser av hverdagslivets erfaringer i 
spenningen mellom godt og vondt, noe man nettopp bruker mytens forestillinger til å beskrive. Det er slik vi må lese det når han på den ene side åpner for en allegorisk, typologisk, metaforisk lesning av tekstene for bibelteologien, og på den annen side forankrer slike lesninger i grupper i jødedommen før og på Jesu tid. Lemche blir aldri litteraturkritiker!

Lemche trekker faktisk lange linjer både i tid og sted: Han vil bruke paralleller i oldtidens Nære Orient til å beskrive de trosoppfattelser GT er en del av; han taler om den monoteistiske bevegelse som fantes i store deler av Den Nære Orient i første årtusen f.Kr. (s. 117f). Han forutsetter åpenbart et samfunn og en kultur i det Østmediterrane rom, som hadde noen hovedtrekk felles og som var gjenkjennelig over lang tid, og denne almene kultur- og samfunnsforstålse vil han bruke til å skrive en bibelteologi. Men det gjenstår å se hvordan denne kultur så ut, og hvor meget vi kan tale om én kultur i området over lengere tid.

Vi må aldri glemme at meningsformasjon og symbolisering er maktmidler i en sosial maktkamp. Lemche er inne på det flere steder i sine bøker. Overser man dette, havner man i det som Lemche, med Sløk, kaller "som-om-sproget" (s. 168). Politisk korrekthet er et godt eksempel på bruken av dette som-om-språk, sier Lemche. Meningsproduksjon og symbolisering har med sosiale interesser å gjøre. Hvem vil at det er noe som skal huskes, og annet som skal glemmes? Religiøs symbolisering er nærmest i alle samfunn, et av de sterkeste midler man har for utøvelse av sosial makt. Ved å fremstille de religiøse symboler som objektive sannheter, immuniserer man seg mot kritikk av egen virkelighetstolkning og i neste instans, av den makt man $ø$ nsker å symbolisere.

Det er i denne kontekst at jeg forstår Lemches prosjekt, slik det fremkommer i de to omtalte bøker, og da særlig med én problemstilling: Hvordan former man nasjonal/etnisk/religiøs identitet gjennom å erindre fortid, sagt på en annen måte, gjennom konstruksjon av fortid?

Dette skjer akkurat nå gjennom et nytt "københavnerprosjekt" slik det er presentert på fakultetets hjemmesider: Centre for Bible and Cultural Memory, hvor Lemche er sentral figur, med prosjektledelse og idéskapning av centrets leder Pernille Carstens.

Hvorledes kan man i bibelvitenskapen forstå GT som "kulturell symbolisering av sosial struktur"? Selve begrepet "sosial struktur" kan binde en til en funksjonalistisk samfunnsmodell i stedet for en hermeneutisk eller humanistisk. Mens samfunnsfag studerer nærværende samfunn vesentlig som prosess, har vi jo ikke tilgang til noe sådant for antikke samfunn. Ikke bare det. Hvordan forankrer man de gtl 
tekster som kultur relatert til en sosial struktur, i et samfunn som det (eller de) førkristent jødiske, en kultur som har etterlatt seg så ringe spor og samfunn vi vet så lite om? Særlig blir dette problematisk i forhold til teorier som vektlegger vilje og refleksjon bak menneskers adferd.

Hvor kan man da forankre Lemches anliggende for antikkens samfunn? Her stanser Lemches fremstilling og man må selv forfølge hans anliggende videre. Etter mitt syn må det $\mathrm{i}$ hovedsak bli i de andre kulturelle artefakter, som datidens samfunn etterlot seg: Andre tekster, bygninger og monumenter inkludert gravskikker, konstruksjon av byer og kultivering av landskap, osv. GT er ett kulturelt artefakt, et arbitrært sådant, i forhold til alle de andre kulturelle artefakter vi har, og ved hjelp av dem må vi så langt det lar seg gjøre, rekonstruere den kultur våre tekster var en del av og den kulturelle symbolisering tekstene målbærer. Bare på den måte kan vi komme i retning av den objektive forståelse som Lemche etterlyser. 